\title{
Thoughts on the Policy of Détente in Europe *
}

\author{
by the Federal Chancellor \\ Bruno Kreisky
}

On the occasion of the signature of the Helsinki Final Act at the Conference on Security and Co-operation in Europe, I stated that there was little point in minimizing the fundamental differences between these different political systems and social structures, or indeed in disregarding them altogether. Allow me to quote a passage from this speech :

"We are therefore ready for the discussion, and we also welcome the Conference on Security and Co-operation in Europe because the principles which have been worked out should allow this world-wide discussion in a peaceful manner. In any case, this is how we understand that view contained in the statement of principles, which affirms the right of each participating state freely to choose and develop its own political, social, economic and cultural system."

This sounded somewhat like a challenge to the communist countries, and many representatives of these countries did not react very favourably.

I could indeed mention quotations from Kruschev - who, rather more so than Lenin, is the true "father of co-existence" - which show that the idea of co-existence has always been considered not to apply in matters of ideology.

It may be objected that the Kruschev era belongs to the past. In this connection, I should like to take an example of an authoritative interpretation.

The February 1977 issue of the journal "Der Kommunist" contains an article, published in the "Daily Review" of the Novosti Press Agency, under the title "in the Forefront of the Ideological Struggle", which makes a number of basic remarks concerning détente and ideological contest.

The author, L. TOLKUNOV, clearly states that, in the last quarter of the 20th century, confrontation has embraced all aspects of social life, but is particularly manifest in matters of ideology :

"One of the salient features of international development is based on the fact that the last quarter of the 20th century has begun and is proceeding in an atmosphere of deepening class confrontation between the forces of progress and reaction, socialism and monopoly capitalism.

* Presented in Vienna to the General Assembly of the "Geneva Association" on 10th July 1978. 
This confrontation embraces all aspects of social life but is particularly manifest in ideology - a domain where there is no, and cannot be any, peaceful co-existence."

The author stresses that :

“As comrade Brezhnev emphasized in the report to the 25th Party Congress, the positive changes in world affairs and détente create favourable opportunities for the broad spread of socialist ideas.

But, on the other hand, the ideological contest between the two systems is becoming ever more acute, and imperialist propaganda ever more subtle."

TOLKUNOV comes to the clear conclusion that the policy of détente is confined to relations between states, and not between classes and social groups. There is no question of the socialist camp accepting a package deal containing political and ideological concessions.

I feel certain that this particular emphasis on the ideological aspects is doubtless the reply to the increased attention paid to human rights since President Carter came to office. It would, however, be a disastrous error to think that this sharpening of the ideological situation has been provoked by it.

I therefore believe that even if there is still a strong support for the policy of détente in Europe, it is essential to realize the true situation, namely that there is certainly no decrease in the ideological differences between the communist and democratic countries.

All proponents of the view that increased détente might lead to a sort of convergence between the two systems are only cherishing absolutely unjustified illusions.

If one thing is certain it is that international détente with liberalization - restricted though it may be - is perhaps more tolerable than the tension-fraught atmosphere of a cold war. But to imagine that the Helsinki Final Act and its Basket III will help to turn the communist states away from communism, and cause them to renounce important elements in their system of supremacy is as illusory as the earlier idea that one could buy the communists out of communism by granting them large credits.

I now come to my first conclusion. I consider that the policy based on the respect of human rights, as conducted by the Western democracies, in no way jeopardizes the policy of détente.

It is no more harmful than the efforts of the communist countries to prove to the world that their system is the most admirable one, in which their avowed aim has always been to make the world "safe for communism".

The argument can, of course, be defended only if one is convinced, as I am, that the policy of détente is not a consequence of a greater human insight, but simply results from the reality of a military equilibrium.

It is really not important whether the number of tanks on one side balances that on the other, and in any case we know that this is not the case.

What really matters is the "overkill capacity" of each side. Professor Victor WEISSKOPF, the great atomic scientist, recently remarked to the American Physical Society : 
"The Soviet Union and the USA assemble increasing numbers of bombs, and perfect their efficiency and their mode of delivery. More than 50,000 nuclear bombs are deployed and ready for us. Both powers now have the capability of destroying the other country many times over."

This equilibrium does exist - I admit, it is somewhat precarious - but that impressive example which Oppenheimer gave at the beginning of the nuclear age is still valid today. He said that the two superpowers resembled two scorpions enclosed in a bottle, each trying to kill the other, but only at the cost of its own life.

This leads, I believe, to the next conclusion for the policy of détente :

If it is true that the balance of power is a prerequisite for the policy of détente, then détente will also be endangered by any change in this balance. What the policy of détente does not permit, therefore, is unilateral disarmament.

May I now turn to the question : who gains from the policy of détente?

One increasingly comes across people in the West who support the view that the policy of détente is advantageous to the communist countries, it offers them a certain degree of security and a certain breathing space which they badly need, because otherwise, if exposed to pressure from without, they would run into very serious difficulties of internal opposition which might even spell their ruin.

But this appears to be one of the main and constantly recurring illusions of our times - apart from the fact that dictatorships may demand from their people much greater sacrifices for armament purposes than the democracies are able to provide, since they have parliamentary systems.

The Soviet ambassador MAYSKY reports in his mémoires that, in the early days after the outbreak of war between Hitlerian Germany and the Soviet Union, he had discussions with Lord Beaverbrook and raised the question of a second Front.

Beaverbrook listened to him attentively, and then finally said :

"Everything you say is all well and good, but..." he paused a while, peered at him closely and added "May I be perfectly frank with you ? ... Are you really also going to fight? Won't the same thing happen to you as happened with France?"

However one may stand in relation to communist regimes, any hope of producing the internal collapse of even one of these regimes is in my opinion doomed to failure.

A political regime which has survived the Second World War, during which Nazi soldiers penetrated into the very heart of the Soviet Union, cannot so easily be brought to its knees.

The changes inside the communist countries must be the affair of the peoples concerned, and cannot be brought about by political pressure from outside.

Quite apart from this, I cannot, for reasons of principle, personally identify myself with the concept of exercising external pressure.

Certainly, the policy of détente is by definition a policy which is useful to the Soviet Union. But I maintain that it is no less useful to the Western democracies.

Allow me to illustrate my point with an example, that of Germany. 
The policy of détente would have been quite unthinkable in Europe if, in its time, the Brandt-Scheel government, and later the Schmidt-Genscher government, had not brought about the normalization of relations with the Soviet Union, the communist States in Europe and finally, after a certain period of time, the GDR.

If the area of tension around Berlin and along the demarcation line separating the two countries had continued to exist with the same acuteness as in the past, there would have been no policy of détente in Europe.

Thus the realistic policy of the Federal Republic of Germany has essentially contributed to the policy of détente, just as in 1955 the treaty of the then Allies with Austria played a similar role.

The policy of détente, as you have seen from the two examples I have quoted, has already much to its credit. One has only to think of all the areas of tension which came into being during the cold war and are no longer referred to today, simply because they no longer exist.

And most important of all : how often in the history of this continent has there been a quarter of century unmarred by war? In this century alone, there were, within 25 years, two devastating wars, the First in 1914 and the Second in 1939.

Although the policy of détente has, in my opinion, only positive aspects, there is a danger of its falling into stagnation.

I should say that the policy of détente is made more stable if it is constantly rendered more comprehensive and put into firmer practical form.

I have given some examples of this in previous statements and speeches. I should like to do this again today :

The energy situation in Europe is marked by the fact that up to $60 \%$ of the energy supplies of the West-European industrialized nations depend on imported energy. This situation is certainly eased by British and Norwegian oil, but it does not make much difference to the vast dependence of the West-European nations on imports.

The East-European countries too - with the exception of the Soviet Union are dependent on foreign suppliers for their energy raw materials. Everyone knows, however, that the Soviet Union is one of the greatest petroleum producers in the world, and that Poland has immense coal-fields.

There is no doubt that an overall co-operation may be achieved in the field of energy, which is not only conceivable but even realizable, so that a strong measure of agreement could be reached between the Eastern and Western economies.

Each year, Austria purchases some 2.4 billion cubic meters of natural gas from the Soviet Union. In 1976, the European countries of the OECD bought some 21.6 billion tons of coal from Poland.

In 1975, Austria concluded an electricity supply agreement with Poland, which is noteworthy for a number of reasons. The electricity purchased, amounting to $400 \mathrm{MW}$ over 4000 operating hours per annum, is supplied through the CSSR's network, and the guarantee for the supply was provided by Poland.

In this way, the network of the West European countries is for the first time 
connected to the network of the COMECON countries. The collaboration promises to be very profitable ; at the instigation of Poland, talks are already under way for a possible increase during the mid-80's in the quantity of electricity supplied.

Or let us take another example :

Europe has a serious transport problem, one which can only be solved on a European scale.

For a country situated in the heart of Europe, with only a limited transport development capability, this question is one of considerable urgency.

Just imagine that Austria, which has become a modern industrialized nation, is unable to transport out of the country a 250-ton plant - in other words a weight of 250 tons ! - simply because we do not have a suitable waterway.

Whenever VÖEST, our largest contractor, has to transport goods on the waterways, they must be unloaded at Regensburg on to the railway network and again re-embarked at Nurenberg.

It is precisely for this reason that we are so urgently awaiting the early completion of work on the Rhein-Main-Danube canal, the so-called Europe-canal.

You can imagine how much this impedes our economic development, and how great the transport problems are for those countries situated in the middle of Europe ; and we are certainly not alone...

There is also Southern Germany, Hungary and even Czechoslovakia. It is a problem which affects European democracies and European communist states alike.

I feel an important approach is to speak in practical terms to each other, in order to find a way of solving this whole question more quickly and efficiently.

Let us now take a third example, the question of how much one can actually lend to the East. We have seen that the indebtedness of the Eastern countries has increased rapidly in recent years. We overlook, however, that the volume of West-East trade rose from 15 billion dollars in 1970 to about 57 billion dollars in 1977.

The Soviet political economist BOGOMOLOV predicted that this figure would rise to 80 billion dollars by 1980 .

This is accompanied by a rather interesting development. Ten years ago, the communist States, the COMECON countries, conducted two-thirds of their trading among themselves.

Today, as their volume of trade is much greater, this figure has now fallen to $50 \%$. Over the same period, the Soviet Union has increased its volume of trade with the West by $250 \%$; its trade has increased four-fold with Austria and five-fold with the Federal Republic of Germany.

There are now various estimates of the degree of this indebtedness. The "Vienna Institute for International Economic Comparisons" estimates that in 1977 the debt to the West amounted to some 46 billion dollars. The Chase Manhattan Bank arrives at a somewhat higher figure (47 billion dollars). 
If one tries to calculate the net value of the debt, in other words the debts after deducting the investments in the Western banks, the figure obtained by the experts is about 39 billion dollars. Hungarian economists told me that it was, in fact, much less.

The error made in the West, they say, is to add to the credit agreement the actual utilization of this credit, which produces an erroneous figure. I do not know how right this is ; in any case, there is this inscreasing indebtedness, and there is the increasing trade which is the cause of this indebtedness.

The question which arises is whether this is dangerous. I would say clearly and unequivocally that I do not think it is at all dangerous ; that I consider the preoccupations expressed here today are not really well-founded because in 1976 the net debt of all COMECON countries amounted to about $4 \%$ and to only $1.8 \%$ in the case of the Soviet Union.

The extent of this debt does not seem to me to be at all alarming, especially if one takes into account the immense wealth, especially of the Soviet Union, in terms of oil, gas, coal, gold and other important raw materials, and if one realizes that a large part of the loans are used for the faster development of these resources, and these have in turn led to increased trading with the West.

There is no question, therefore, of there being only one-sided advantages. In any case, an increased economic co-operation between East and West would certainly be favourable to the economy of the East-European countries, because, despite this remarkable expansion in the economy of these countries, a phase of weaker growth is clearly recognizable.

In many countries, the overall economic productivity during the first two years of the current five-year plans lagged behind the planned targets owing to the adverse trends in agriculture and foreign trading.

Investment and consumption have grown more slowly than in the first half of the seventies. East-West trade has grown very slowly. Above all, the exports to the Western industrialized nations have not increased at the rate planned, and this has been one of the consequences of the critical development in the West.

Certainly the exchange of goods among the COMECON countries has increased above average. In particular, the smaller countries have become much more dependent on raw material and fuel imports from the Soviet Union.

For all of these reasons, a marked reinforcement in the economic relations between East and West would be desirable, and I am therefore in support of realistic and substantial trade negotiations between the Common Market and Comecon.

The question that should be asked, in this connection, is whether the participating countries have ever had the serious intention of really tackling these questions in Belgrade.

I believe that there was no such intention, since the Belgrade Conference was designed from the outset as a Conference for non-policy making officials.

I should, incidentally, add that the West ought, in my opinion, to make every effort to ensure that the representation at the coming conference in Madrid is raised to ministerial level. 
Only then will it be possible to hope for progress in the policy of détente.

Be that as it may, I am by no means sure that the Soviet Union really wants multilateral solutions on the overall European plane.

The Soviet Union has always seen its trading policy as an instrument serving its foreign policy, and it would hardly be inclined to relinquish this very easily manipulated part of its policy.

However, this should not prevent us from adopting a constructive economic policy in Europe.

If it proved possible, as a result of the policy of détente, to obtain a higher degree of overall European integration, this would be a singular achievement for the development of the European countries.

Over and above this, however, - and this is much more important - a departure from the policy of détente would involve sacrifices which would make any such change of course increasingly difficult.

This brings me to a further conclusion : today it is the West which has to come forward with new, concrete proposals for collaboration with the East, not for tactical reasons but to achieve a greater political solidity.

The most important matter, however, for the policy of détente is still disarmament. It is, so to speak, its corollary. So far, no real achievements have been made here. Everything is poised on the outcome of the SALT discussions.

Indeed, only if the SALT round of talks is successful will it be possible to achieve progress in the Vienna demilitarization talks, if only in homeopathic doses.

The Special Session of the General Assembly for problems of Disarmaments has just completed its work with a final document which to many may appear disappointing.

This Conference has, however, above all shown one thing : that even small - and usually less armed - countries can actively participate in the disarmament debates.

Since the era of the cold war, the Soviet Union and other communist countries have increasingly sought to portray themselves as the true champions of peace, through an unending series of world peace and disarmament initiatives and, what is more, they have met with increasing success in this respect, especially in the eyes of the Third World countries.

This situation could, however, be turned against them if the Western countries - and many countries outside the communist bloc - began to come forward with initiatives for realistic disarmament measures.

Finally, this would also be much more in keeping with the democratic tradition of the West.

In view of the fact that the world at present spends more than 400 billion dollars per year on arms, it is clear that the question of disarmament will increasingly become a question of internal politics and should be followed up with increasing attention.

It may sound like a truism to state that the disarmament policy is indivisible, but this is in fact the case. 
When there are increased tensions in other regions of the world, the major powers will inevitably be involved, and this constitutes a threat to the policy of détente. A region which is of particular importance in this connection is the Near East.

Unfortunately, the democratic countries of Europe have not yet displayed that active interest which should be applied to the handling of the problems in this region, but I can understand that many European countries still have certain hesitations on account of the fate of the European Jews.

It may be that my views on détente are influenced by the fact that $I$ have observed the situation from Vienna, in other words, from Central Europe, and it may seem quite different when seen from other countries. It may appear different, but it is still the same.

And if you ask me why we Austrians are so attached to the policy of détente, I expressed the reason for this too in Helsinki.

Allow me to conclude by saying :

“... we know from our own very bitter experience what is meant by a continent torn by tension. If détente does exist, Austria, which is right the heart of this continent, is nevertheless a blossoming community and a safe homeland for its people.

If it does not exist, then we lie in the sombre shadow of a military and political demarcation line which cuts right across Europe and becomes the dividing line between its military and political systems.

So you will understand why Austria wishes to contribute fully, and why, in keeping clear of all illusions, we are so positively in favour of the concept of détente." 